\title{
About the editors and authors
}

\section{EDITORS}

Annemette Kjærgaard is Professor (MSO) in Management Learning and Development at Department of Management, Society and Communication at Copenhagen Business School, Denmark. She is also Associate Dean of Technology-Enhanced Learning and leads the project Research in Blended Learning. Kjærgaard teaches leadership development and is a Senior Fellow with the Higher Education Academy. Her research program comprises studies in management learning, with a particular focus on the effects of blended learning on student outcomes, implications for student and teacher identities, and organizational changes due to the adoption of technology-enhanced learning. Her research has been published in journals such as European Journal of Information Systems, Journal of Information Technology, Journal of Management Studies and Management Learning.

Adam Lindgreen completed a PhD in marketing from Cranfield University, UK (in 2000), with 18 months spent at the University of Auckland's Business School, New Zealand. Since 2016, Lindgreen has been Professor of Marketing at Copenhagen Business School, Denmark, where he also heads the Department of Marketing. He also is Extraordinary Professor with the University of Pretoria, South Africa's Gordon Institute of Business Science. He serves as co-editor-in-chief for Industrial Marketing Management. Lindgreen's publications have appeared in California Management Review, Journal of Business Ethics, Journal of the Academy of Marketing Science, Journal of Product Innovation Management, Journal of World Business and Organization Studies, among others. Furthermore, his 30+ books include The Emergence and Rise of Relationship Marketing, A Stakeholder Approach to Corporate Social Responsibility (with Kotler, Vanhamme, and Maon; 2012), Memorable Customer Experiences (with Vanhamme and Beverland; 2009), Not All Claps and Cheers (with Maon, Vanhamme, Angell and Memery; 2018), Public Value (with Koenig-Lewis, Kitchener, Brewer, Moore and Meynhardt; 2019), and Sustainable Value Chain Management (with Maon, Vanhamme and Sen; 2013). Beyond these academic contributions to marketing, Lindgreen has discovered and excavated settlements from the Stone Age in Denmark, including the only major kitchen midden - Sparregård - in the south-east of Denmark; because of its importance, the kitchen midden was later excavated by the National Museum and then protected as a historical monument for future generations. He is also an avid genealogist, having traced his family back to 1390 and published widely, including eight books and numerous articles in scientific journals (Personalhistorisk Tidsskrift, Genealogist and Slcegt \& Data), related to methodological issues in genealogy, accounts of population development and particular family lineages.

Eleri Rosier is a Reader in Marketing and Strategy at Cardiff Business School, Cardiff University, UK, as well as a Member of the Chartered Institute of Marketing and a Fellow of the Higher Education Academy. She is also Director of Postgraduate Recruitment and 
Admissions and Programme Director for MSc Strategic Marketing. Her main research interests include strategy processes and implementation, mid-level marketing management, blended learning, live case study teaching and bilingual teaching in higher education. Her work has appeared in European Journal of Marketing, Industrial Marketing Management, Journal of Euromarketing and Journal of Strategic Marketing. Before joining Cardiff Business School, she gained industrial experience in the marketing and event management industry.

Thyra Uth Thomsen is Professor (MSO) of Consumer Research in the Department of Marketing, Copenhagen Business School, Denmark. From 2017 to 2020, she was deputy head of the department, with a special focus on the delivery and development of marketing education. Her research interests lie primarily in consumer transformations and consumption-related individual and societal well-being. In the past, her research has mainly been conducted within the domain of food consumption, particularly related to consumer vulnerabilities and resources. Moreover, she has a keen interest in the scholarship of teaching and learning. She has published in leading journals such as European Journal of Marketing, Journal of Business Ethics, Journal of Business Research, Management Learning and Psychology and Marketing.

Aybars Tuncdogan is Associate Professor in Marketing and Technology at King's Business School, King's College, London, UK. Previously, he worked as a Lecturer in Marketing and Strategy at Cardiff University. He completed his PhD at the Rotterdam School of Management, Erasmus University, the Netherlands. His research employs psychological constructs to understand ways to explain, predict and shape managers', consumers' and collectives' (e.g., teams, organizations, consumer tribes) strategic decisions. He has published in Industrial Marketing Management, Journal of Business Ethics, Journal of Managerial Psychology, Leadership Quarterly, Long Range Planning, Personality and Individual Differences, R\&D Management and Teaching in Higher Education. He has also has co-edited (with Lindgreen, van den Bosch and Volberda) Strategic Renewal: Core Concepts, Antecedents and Micro-Foundations (2019).

\section{AUTHORS}

Kasper Merling Arendt is a doctoral fellow in the Department of Marketing at Copenhagen Business School, Denmark, where he researches the effects of different pedagogical approaches to entrepreneurship education, with a particular focus on design-based ways of teaching. He also is employed at VIVE, The Danish Center for Social Science Research, where he has conducted both small- and large-scale program evaluations of the Danish school system.

Michael B. Beverland is Professor of Marketing and Head of Department (Strategy and Marketing) at the University of Sussex Business School, UK. He is also an adjunct professor with the Copenhagen Business School, Denmark. Beverland received his doctorate from the University of South Australia. His work has been published in Journal of the Academy of Marketing Science, Journal of Advertising, Journal of Consumer Research, Journal of Macromarketing, Journal of Management Studies and Journal of Product Innovation Management, among others. He has published a number of teaching cases with the Harvard Business School and the Case Centre, USA. 
Roderick J. Brodie is Professor of Marketing in the Department of Marketing at University of Auckland, New Zealand. His 120-plus journal articles have appeared in leading international journals including Industrial Marketing Management, International Journal of Research in Marketing, Journal of Marketing, Journal of Marketing Research, Journal of Service Research and Management Science, among others. He is an associate editor for Journal of Service Research and former associate editor for Marketing Theory. He has served on the editorial boards of Journal of Marketing, International Journal of Research in Marketing and other leading international journals. He was the first president of the Australian and New Zealand Marketing Academy (ANZMAC), and in 2004 he was made a founding fellow; in 2011, Brodie was made a fellow of the European Marketing Academy (EMAC).

Peter Bryant is an Associate Professor at the University of Sydney Business School, Australia, where he also serves as an Associate Dean (Education). He has worked as an academic and educational leader in several leading UK and Australian institutions, including the London School of Economics and Political Science, University of Greenwich, and Middlesex University, UK. He received his $\mathrm{PhD}$ in management from the University of Technology, Sydney, Australia. Bryant is a trustee of the Association for Learning Technology (UK) and the chair of the editorial board for the peer-reviewed open access journal Research in Learning Technology.

Leela Cejnar is an interdisciplinary lecturer at the University of Sydney, Australia. She works with the Industry and Community Projects Unit, in the Education Portfolio, Office of the Deputy Vice Chancellor. In this role, Cejnar collaborates with industry, community and government organizations to design and deliver interdisciplinary, experiential learning projects for undergraduate students. She holds a PhD in Law and has published widely in her own discipline, as well as in learning and teaching in higher education. She is a senior fellow of the Higher Education Academy (UK).

Bo T. Christensen is Professor in Creative Cognition at Copenhagen Business School, Denmark. A cognitive psychologist by training, his work centers on cognitive studies of creative, innovative or entrepreneurial practices in the fields of design, business, architecture, engineering and gastronomy. His theoretical focus is on cognitive strategies such as analogy, simulation and incubation, coupled with metacognitive process awareness. He is the Academic Director of CBS Studios, a studio-based learning environment at Copenhagen Business School.

Ad de Jong is Professor of Marketing at Copenhagen Business School, Denmark. He is an expert in the areas of sales management, frontline marketing, service marketing, service innovation and marketing research. In addition to serving on the editorial boards of Journal of Service Research, Industrial Marketing Management and Journal of Personal Selling and Sales Management, de Jong is a frequently invited speaker and member of a wide variety or international fora, including both highly reputed academic institutions and well-respected professional bodies in marketing.

C. Anthony Di Benedetto is Professor of Marketing and Supply Chain Management and Senior Washburn Research Fellow at the Fox School of Business, Temple University, USA. He has held visiting professorships at Bocconi University and Politecnico di Milano (Italy), Technische Universiteit Eindhoven (Netherlands), Kansai University (Japan), Yonsei 
University (Korea), WHU (Germany), St Petersburg State University (Russia), and Edhec Business School and IESEG School of Management (France). In 2010, Di Benedetto was named the Fulbright-Kathryn and Craig Hall Chair in Entrepreneurship and spent a semester at the Wirtschaftsuniversität Wien (Austria). Di Benedetto is co-editor-in-chief of Industrial Marketing Management and editor-in-chief of Journal of International Consumer Marketing. He served as editor of Journal of Product Innovation Management for nine years.

Wim Gijselaers is Full Professor of Educational Research at the School of Business and Economics of Maastricht University, the Netherlands, where he also heads the Educational Research and Development Department. He received his PhD from Maastricht University. Gijselaers has published in Educational Research Review, Small Group Research, Instructional Science, Studies in Higher Education, Academic Medicine, Medical Teacher and European Journal of Psychology of Education, among others.

Linda Greve is Head of Learning at the Science Museums, Aarhus University, Denmak. She holds a PhD in knowledge communication from Aarhus School of Business and Social Sciences. Greve worked for several years as an educational developer in the fields of entrepreneurship and business administration and is an acknowledged teacher trainer. She has published books and papers on research presentation and higher education teaching; her research mainly focuses on the fields of knowledge creation and knowledge dissemination.

Rachael Hains-Wesson is Director of Work-Integrated Learning and an associate professor at the University of Sydney Business School, Australia. She is responsible for leading the scope and scale expansion of the School's Work-Integrated Learning offerings. A Queen Elizabeth II Silver Jubilee Trust for Young Australians Awardee, Hains-Wesson has extensive senior management and leadership experience in entrepreneurship and creative industries.

Elaine Huber is an associate professor at the University of Sydney Business School, Australia, where she is Academic Director of Business Co-Design. Huber received her PhD in educational evaluation from Macquarie University, Australia and is a leading researcher in the field of educational development and learning technologies, with a teaching philosophy that takes a student-centered approach. She is an active member of the Australasian Society for Computers in Learning in Tertiary Education (ASCILITE) community, reviews for Australian Journal of Educational Technologies, and has published in journals such as Studies in Educational Evaluation, International Journal of Educational Management and Evaluation Journal of Australasia.

Alan Irwin is a professor in the Department of Organization at Copenhagen Business School, Denmark. From 2015 to 2018, he was also the school's Vice-President of Entrepreneurship and Innovation. Between 2007 and 2014, he was Dean of Research and, for a period, served as the Acting President. His PhD is from the University of Manchester, UK, and he has held academic positions at Manchester, Brunel and Liverpool universities, UK. He is currently the principal investigator on a research project examining research and innovation policies in China, Denmark and the United States. He has published in Environment and Planning A, Minerva, Public Understanding of Science, Science, Technology, and Human Values, Social Studies of Science and Sociological Review, among others. 
Marian Iszatt-White is a senior lecturer at Lancaster University Management School, UK, where she also is Director of the School Doctoral Programmes. Iszatt-White received her $\mathrm{PhD}$ from Lancaster University, as part of the Centre for Excellence in Leadership. She has published in International Journal of Management Reviews, Journal of Business Ethics, Management Learning and Leadership, as well as co-authoring a successful postgraduate leadership textbook.

Kaiying Ji is a lecturer in accounting at the University of Sydney Business School, Australia. $\mathrm{Ji}$ has a PhD in accounting and is a member of Certified Practising Accountant (CPA) Australia and the Chartered Financial Analyst (CFA) Institute. She has extensive experience teaching accounting, work-integrated learning and business units. Her research areas include work-integrated learning, financial reporting and intangible assets.

David Kember is Professor in Curriculum Methods and Pedagogy in the Education Faculty of University of Tasmania, Australia. Prior to this appointment, he worked in universities in Hong Kong for 25 years, including six years spent running an interinstitutional initiative across the eight universities in Hong Kong, known as the Action Learning Project. It supported 90 action research projects, in which teachers introduced a wide variety of initiatives to improve the quality of student learning. His work in the following areas has been widely cited: student approaches to learning and the influence of teaching and assessment on them; the Chinese and Asian learner; motivation; reflective thinking; teachers' beliefs about and approaches to teaching; action learning and research for teaching quality improvement; and online and distance education.

Rushana Khusainova is a lecturer in marketing at Aston Business School, UK. Her research centers on salesperson motivations and work-life balance, as well as ritualistic consumption. Her teaching-related interests include gamification and game-based learning, infused curricula and student mental health.

Bernadett Koles is an associate professor in the Department of Marketing and Sales Management at IESEG School of Management. Koles received her EdD from Harvard University Graduate School of Education, USA, and her PhD from Durham University Business School, UK. She has published in Current Opinion in Psychology, Journal of Business Research, Psychology and Marketing, Industrial Marketing Management and Journal of Marketing Management, among others, and she serves as an associate editor for International Journal of Consumer Studies.

Carolin Kreber is Professor of Education at Cape Breton University, Canada. From 2015 to 2020, she served as Dean of the School of Education and Health. From 2005 to 2015, she held the Chair of Teaching and Learning in Higher Education at Edinburgh University, UK, where she also directed the Centre for Teaching, Learning and Assessment and led the postgraduate Certificate in Academic Practice. In 2010, she founded the Higher Education Research Group at Edinburgh University and assumed the role of Institute Director of Research two years later. Kreber received her PhD from the University of Toronto, Canada. She taught and developed many courses at Brock University and University of Alberta, Canada, and Edinburgh University. Kreber is the author of many articles and books in the field of education; her most recent book is Educating for Civic-Mindedness: Nurturing Authentic Professional Identities through Transformative Higher Education (2017). 
Barbara Larson is Executive Professor of Management at the D'Amore-McKim School of Business at Northeastern University, USA. She earned her DBA from Harvard Business School in Management, USA, and her MBA from the Wharton School, University of Pennsylvania, USA, in Finance and Operations Management. She has published in Management Science, Academy of Management Perspectives, Management Teaching Review and Harvard Business Review, among others.

Sabine Lauer is a postdoctoral researcher at the Chair of Organizational Studies, Continuing Education and Social Management at TU Dortmund University, Germany. Lauer received her PhD from TU Dortmund University in 2019. In her cumulative dissertation, she dealt with "Transformational Governance of Academic Teaching." She has published on higher education in Studies in Higher Education, Learning Organization and Tertiary Education and Management. In addition, Lauer holds a Master's degree in biostatistics, in which field she also has published in American Statistician and PLOS ONE.

Catherine Leviten-Reid is an associate professor at Cape Breton University, Canada and teaches in the MBA in Community Economic Development program in the Shannon School of Business. Her research pertains to the social economy, affordable housing and community development, and her articles have appeared in journals including VOLUNTAS: International Journal of Voluntary and Nonprofit Organizations and Nonprofit and Voluntary Sector Quarterly. Leviten-Reid's research is primarily conducted in partnership with community-based organizations; she currently is leading a five-year, pan-Canadian research initiative on affordable housing for those in greatest need. Her PhD is from the University of Wisconsin-Madison, USA.

Maria Luksich is the Work-Integrated Learning Programs Manager at University of Sydney Business School, Australia. She has postgraduate degrees in education (career development) and communications management from Queensland University of Technology and the University of Technology Sydney, Australia.

Stephanie MacPherson is a senior instructor in the Bachelor of Hospitality and Tourism Management program in the Shannon School of Business at Cape Breton University, Canada. MacPherson joined the faculty at Cape Breton University after more than 15 years' practitioner experience in different sectors and levels of the tourism, hospitality and event management industries, as well as administrative roles in higher education in both Canada and the United States. Her Master's degree in tourism administration reflects a concentration in sustainable destination management, from George Washington University, USA. She also earned a Bachelor of Applied Management in Hospitality and Tourism from the University of New Brunswick, Canada. She has published in the Journal of Aboriginal Economic Development.

Lilia Mantai is a lecturer at University of Sydney Business School, Australia and Academic Lead for Course Enhancement, where she currently oversees the assurance of learning and guides curriculum development and assessment design. Mantai graduated with a $\mathrm{PhD}$ from Macquarie University, Australia, in 2017, with a thesis on the researcher identity development of $\mathrm{PhD}$ students and the role of social support. She has published in higher and doctoral education journals, including Studies in Higher Education, Teaching in Higher Education, International Journal for Researcher Development, International Journal of Doctoral Studies 
and Australian Educational Researcher. She is a senior fellow of AdvanceHE and associate editor for Higher Education Research and Development.

Stefan Meisiek is an associate professor in the Strategy, Innovation and Entrepreneurship discipline at the University of Sydney Business School, Australia. He received his PhD in Management from the Stockholm School of Economics, Sweden and his MA from the Free University, Berlin, Germany. He researches leadership, strategy, and business innovation. He has a particular interest in how leadership and strategic choices enable or constrain innovation efforts, such as motivating organizational members to inquire into pernicious problems; challenging basic assumptions; and granting licenses for dreaming, imagining and creating. He has worked with many companies, government agencies and non-governmental organizations on innovation projects.

René W.J. Moolenaar is a senior lecturer and associate professor in the Strategy and Marketing Department of the University of Sussex Business School, UK. He is also a board member for multiple creative and technology-led innovative organizations. He has published a video case study within the Pearson Revel compendium to Global Marketing (with Hollensen, 2020).

Peter Naudé graduated in marketing from the University of Cape Town, South Africa, and then in operations research from the University of Sussex, UK. After teaching at the Graduate School of Business in Cape Town, he went to Manchester Business School, UK, where after completing his PhD he joined the staff. Between 1999 and 2005, he was Professor of Marketing at the University of Bath's School of Management, UK, before returning to Manchester Business School in 2006. Naudé was Deputy Director of Manchester Business School between 2006 and 2012, and he retired in 2017. He currently holds joint appointments at Manchester Metropolitan University Business School and with the Discipline of Marketing at the University of Sydney, Australia.

Alyson Nicholds is Associate Professor of Business Management at Staffordshire Business School, UK, where she leads programmes in postgraduate research and draws on critical discourse theory to teach about leadership. In her teaching, writing and research, she draws reflexively on this experience, together with her professional background in healthcare and urban development, to make sense of how different actors lead for social purposes in complex times. Nicholds received her $\mathrm{PhD}$ from the Institute of Local Government Studies at the University of Birmingham, UK, and her work has been published in high-ranking journals including Public Management Review, International Business Review, Management Learning and Regional Studies.

Loïc Plé is Director of Pedagogy and Head of the Center for Educational and Technological Innovation (CETI) at IESEG School of Management. He is also an associate professor in the Department of Innovation, Entrepreneurship, and Information Systems. Plé received his $\mathrm{PhD}$ from Paris Dauphine University, France. He has published several papers in Journal of Business Research, Journal of Services Marketing, M@n@gement and Journal of Business Strategy, among others, as well as more than 20 case studies. He has also coordinated a book of case studies in strategic management. 
Nicola Reimann is an academic developer in the School of Education and Durham Centre for Academic Development at Durham University, UK. She has developed, led and taught a wide range of modules and programs pertaining to learning and teaching in higher education for staff. Reimann received her PhD from Newcastle University, UK. Her research, focused on assessment and feedback in higher education and the development of academics, has been published in journals such as Assessment and Evaluation in Higher Education and International Journal for Academic Development. She is currently principal investigator of a European Erasmus + funded project on intercultural reflection on teaching, and a member of the degree standards project team which is responsible for developing and delivering professional development for external examiners across England, Wales and Northern Ireland.

Torsten Ringberg received his MBA, MA (Psychological Anthropology) and PhD in marketing from US universities. He publishes in top-tier international academic business journals, such as Journal of Marketing, Journal of Consumer Research, Journal of Management Studies, Annals of Tourism Research and Research in the Sociology of Organizations. He teaches masters and $\mathrm{PhD}$ courses, as well as courses in the executive and summer programs, and has won several teaching awards in the United States and Denmark. Ringberg also applies academic insights to work for leading US and European organizations.

Ian Sadler is a subject leader in the School of Sport and Exercise Science at Liverpool John Moores University, UK. He has developed, led and taught a wide range of modules and programs related to sport and academic development for staff in higher education. Sadler received his $\mathrm{PhD}$ from University of Edinburgh, UK. His research focuses on teacher development, as well as assessment and feedback in higher education. He has published in journals such as Studies in Higher Education and Assessment and Evaluation in Higher Education. He is currently a member of the degree standards project team which is developing and delivering professional development for external examiners across England, Wales and Northern Ireland.

Yasin Sahhar is a strategic marketing consultant at The Next Organization and a $\mathrm{PhD}$ researcher in the research group for Entrepreneurship, Strategy and Innovation Management at University of Twente, the Netherlands. In his consultancy work, he helps industry leaders address strategy and marketing-related challenges. His research interest lies in value creation and value experience, from a service logic perspective, and he has presented and published his work at several conferences.

Kay Sambell is Professor of Higher Education Pedagogy at Edinburgh Napier University, UK. She is also an honorary professor at the University of Cumbria, UK, and president of the internationally acclaimed Assessment in Higher Education conference. She is known for co-leading the ground-breaking Centre for Excellence in Teaching and Learning in Assessment for Learning at Northumbria University, UK. Sambell received her PhD from the University of York, UK. She co-authored the widely cited text on Assessment for Learning in Higher Education with Catherine Montgomery and the late Liz McDowell, and has published in Assessment for Learning in Higher Education, Studies in Educational Evaluation, Quality in Higher Education and Advance HE, among others. She is a UK National Teaching Fellow (2002) and holds Principal Fellowship in the Higher Education Academy.

Sandra Seno-Alday is a lecturer at the University of Sydney Business School, Australia, where she is also director of the program for high-achieving students. Extending her expe- 
rience in strategy and organization development consulting, her scholarly and industry research explores global dynamics, international business governance, risk and sustainability. Committed to excellence and innovation in higher education, Seno-Alday is a recipient of an Australian Learning and Teaching Council Citation for Outstanding Contributions to Student Learning.

Maryam Shahbazi is a $\mathrm{PhD}$ candidate and research assistant at the University of Sydney Business School, Australia. She has completed her MPhil in social network analysis at the University of Sydney. Her professional background spans international business development, market research and project management experience, and she has led complex projects. Shahbazi also holds a Master's degree in project management from the University of Sydney and an Executive Master's in business administration from Iran. Her research areas include social media and crisis management and influential factors in online social networks.

Michael Sweet is Director of Design and Integration at Northeastern University's Center for Advancing Teaching and Learning through Research, USA. He earned his PhD from the University of Texas, Austin, USA in educational psychology, and has published in Educational Psychology Review, Journal on Excellence in College Teaching, Decision Sciences, Journal of Innovative Education, To Improve the Academy and New Directions for Teaching and Learning, among others.

Stina Teilmann-Lock is associate professor in the Department of Management, Politics and Philosophy at Copenhagen Business School, Denmark. Her research focuses on intersections of law, design and technology, and she has published widely on intellectual property law, design and digital transformations.

Piet Van den Bossche is Full Professor of Learning in Organizations at the Faculty of Social Sciences, University of Antwerp, Belgium, where he heads the Department of Training and Education Sciences. He is also an associate professor at the School of Business and Economics at Maastricht University, the Netherlands. Van den Bossche received his PhD from Maastricht University. He has published in European Journal of Psychology of Education, Educational Research Review, Small Group Research, Instructional Science and Human Resource Development Quarterly, among others.

Florence Villesèche is associate professor and Academic Director of the Business in Society platform for Diversity and Difference at Copenhagen Business School, Denmark. She is a Marie Curie alumna and received an Emerald/EFMD Highly Commended Award for outstanding doctoral research. Her published works include books and chapters on diversity, identity and networks, along with contributions to recognized outlets such as Human Relations, European Management Review, Personnel Review, ephemera and Equality, Diversity and Inclusion. Her main research interests are networks, gender and diversity, identity and the corporate elite.

Sylvia von Wallpach is Professor (MSO) in Branding and Marketing Management at the Department of Marketing at Copenhagen Business School, Denmark. Her main research interests are in the fields of branding, interpretative consumer research and qualitative method development. Von Wallpach is a senior fellow with the Higher Education Academy and has contributed to the development of online and blended learning. Her research has been pub- 
lished in Tourism Management, Journal of Business Ethics, Journal of Business Research and Psychology and Marketing and she has been awarded international prizes (e.g., SAGE Social Science Space Impact Contest 2020).

Leslie Wardley is Associate Professor of Marketing in the Shannon School of Business and a Social Sciences and Humanities Research Council (SSHRC) Exchange University Research Chair in Social Determinants of Health (2019-2022) at Cape Breton University, Canada. She holds adjunct status in Ryerson University's Department of Mechanical and Industrial Engineering within its Faculty of Engineering and Architectural Science, and in Nipissing University's School of Business, both in Cananda. Wardley began her professional career in small business management and later expanded her expertise to university administration. After shifting from administration to become a faculty member, she continued to concentrate her efforts on higher education policies and administration. Her $\mathrm{PhD}$ (Laurentian University, Canada) focused on the co-creation of value and the institutional commitment of students in the post-secondary sector. This work garnered an award for the best doctoral thesis in the field of higher education in Canada (2015), bestowed by the Canadian Society for the Study of Higher Education. The findings were published in Higher Education: The International Journal of Higher Education Research.

Uwe Wilkesmann has been a professor at TU Dortmund University, Germany since 2006, where he is also director of the Centre for Higher Education. From 2008 to 2015, he was an adjunct professor at Hong Kong Polytechnic University. Wilkesmann received his doctorate and habilitation at Ruhr University Bochum, Germany. He has published on higher education research, organizational research and knowledge transfer in Organization Studies, Higher Education, Studies in Higher Education, Tertiary Education and Management, VINE Journal of Information and Knowledge Management Systems, Journal of Knowledge Management and Evidence-Based HRM.

Stephanie Wilson is a senior lecturer at University of Sydney Business School, Australia, where she is Deputy Director of Business Co-Design. Wilson received her PhD from University of New South Wales, Australia, and is a senior fellow of Advance HE. She has published in journals such as Design Issues, International Journal of Art and Design Education, International Journal of Design Education and British Journal of Educational Technology.

Sonja Zaar is a lecturer and researcher on leadership, learning and development at the School of Business and Economics, Maastricht University, the Netherlands. She received her MBA from TIAS School for Business and Society, the Netherlands, and is currently a PhD candidate at Maastricht University. Her research interests include leadership development, leader identity, cognitive schemas, self-regulation and learning from experiences. She has published in Academy of Management Learning and Education and has presented her work at the European Association of Work and Organizational Psychology conferences. 